\title{
GENERAL EULER-BOOLE'S AND DUAL EULER-BOOLE'S FORMULAE
}

\author{
I. FRANJić, J. PeČARIĆ AND I. PERIĆ
}

\begin{abstract}
The aim of this paper is to derive general Euler-Boole's and dual Euler-Boole's formulae. More precisely, we derive formulae of Boole type where the integral is approximated not only with the values of the function in certain points but also with values of its derivatives up to $(2 n-1)$-th order in end points of the interval. Our method produces formulae of arbitrary degree of exactness. Dual Euler-Boole's formulae are derived by analogy with Simpson's and dual Simpson's rule, and Simpson's 3/8 and Maclaurin's rule. Finally, by analogy with BullenSimpson's and Bullen-Simpson's 3/8 inequality, general Bullen-Boole's inequality for a class of $(2 k)$-convex functions is derived.
\end{abstract}

Mathematics subject classification (2000): 26D15, 65D30, 65D32.

Key words and phrases: Extended Euler formulae; multiplication theorem for Bernoulli polynomials; Boole's quadrature formula; dual Boole's quadrature formula; sharp estimates of the quadrature formulae; Bullen-Boole's inequality, $(2 k)$-convex functions.

\section{REFERENCES}

[1] M. ABRAMOWITZ AND I. A. STEGUN (EDS), Handbook of mathematical functions with formulae, graphs and mathematical tables, National Bureau of Standards, Applied Math. Series 55, 4th printing, Washington, 1965.

[2] P. S. BULLEN, Error estimates for some elementary quadrature rules, Univ. Beograd Publ. Elektrotehn. Fak. Ser. Mat. Fiz., 602-633, (1978), 97-103.

[3] P. J. Davis AND P. RABINOwITZ, Methods of Numerical Integration, New York, 1975.

[4] LJ. Dedić, M. MATIĆ AND J. PeČARIĆ, On generalizations of Ostrowski inequality via some Euler-type identities, Math. Inequal. \& Appl., 3, 3 (2000), 337-353.

[5] LJ. Dedić, M. Matić AND J. PeČARIĆ, On Euler-Simpson formulae, Pan. Amer. Math. J. 11, 2 (2001), 47-64.

[6] LJ. Dedić, M. Matić And J. PeČARIĆ, On dual Euler-Simpson formulae, Bull. Belg. Math. Soc. 8, (2001), 479-504.

[7] LJ. Dedić, M. MatiĆ And J. PeČARIĆ, On Euler-Maclaurin formulae, Math. Inequal. \& Appl. 6, 2 (2003), 247-275.

[8] LJ. Dedić, M. Matić, J. PeČARić And A. Vukelić, On Euler-Simpson 3/8 formulae, (to appear in Nonlinear Studies)

[9] P. C. HAMMER, The mid-point method of numerical integration, Math. Mag. 31, (1957-58), 193-195.

[10] V. I. KRYLOV, Approximate calculation of integrals, Macmillan, New York-London, 1962.

[11] M. MATIĆ, J. PeČARIĆ AND A. VuKelić, On generalization of Bullen-Simpson's 3/8 inequality (to appear in Mathematical and Computer Modelling).

[12] M. Matić, J. PeČARIĆ AND A. VUKelić, On generalization of Bullen-Simpson's inequality (submitted for publication).

[13] J. PeČArić, I. Perić And A. Vukelić, On Euler-Boole formulae, Math. Inequal. \& Appl., 7, 1 (2004), $27-46$.

[14] J. PEČARIĆ, I. PERIĆ AND A. VUKelić, Sharp integral inequalities based on general Euler two-point formulae, ANZIAM J 46 (2005), 1-20.

[15] A. W. Roberts And D. E. VARBERG, Convex Functions, Academic Press, New York, 1973.

[16] N. UJEVIĆ AND A. J. ROBERTS, A corrected quadrature formula and applications, ANZIAM J. 45, E 41-56, (2004) 